\title{
Avoimen korkeakoulun avoimet ongelmat
}

Tuomisto, Jukka. 1981. Avoimen korkeakoulun avoimet ongelmat. Aikuiskasvatus 1,2, 68-69. - Artikkelissa tarkastellaan kriittisesti Avoimen korkeakoulun toimikunnan mietintöä. Siinä todetaan mm. että avoin korkeakoulu ei ole onnistunut sivistyksellisen tasa-arvoisuuden edistämisessä ja että yliopistojen kansansivistystehtävä on kehittämisessä unohdettu lähes kokonaan. Kirjoittajan mielestä avoin korkeakoulu olisi ensisijaisesti nähtävä osana korkeakoululaitoksen kehittämistä.

Avoimen korkeakoulun toimikunta jätti mietintönsä (KomM 1981:36) opetusministerille elokuun viimeisenä päivänä. Maan suurin päivälehti totesi, että toimikunnan mietintö jäi odottamattoman yleisluonteiseksi; sitä luonnehdittiin myös askeleeksi, joskin lyhyeksi, kohti koulutuksellista tasa-arvoa. Mietintö on todella jäänyt valitettavan yleisluonteiseksi ja vähän uutta tietoa antavaksi. Pääasiassa mietinnössä kerrataan samat asiat, mitkä ovat jo vuonna 1976 ilmentyneessä Suomen kulttuurirahaston asettaman Avoimen korkeakoulun toimikunnan mietinnössä.

\section{Avoin korkeakoulu ja tasa-arvo}

Avointa korkeakoulua on vaivannut koko sen kehittämisen ajan harhaluulo, että se toimii keskeisenä välineenä sivistyksellisen tasaarvon lisäämisessä. Kuitenkin kaikki asiasta tehdyt tutkimukset osoittavat yksiselitteisesti, että arvosanaopetukseen osallistuvat pääasiassa suhteellisen hyvän koulutuksen saaneet henkilöryhmät; kansakoulun käyneet (joita aikuisväestöstämme on sentään edelleen yli puolet) ovat sen sijaan (suhteellisesti) selvästi aliedustettuina opiskelijoiden keskuudessa. Jotkut poikkeukset eivät asiaa miksikään muuta. Tämä on luonnollista, kun otetaan huomioon opetuksen lähtötaso ja se, että toistaiseksi ei ole tehty mitään olennaisia parannuksia näiden väestöryhmien mukaansaamiseksi.

Toimikunta on kuitenkin ottanut sivistyksellisen tasa-arvon edistämisen jopa avoimen korkeakoulun määritelmäänsä. Tälle periaatteelle ei voi antaa suurta arvoa, koska se ei ole pohtinut, mitä sivistyksellisen tasa-arvon lisääminen todella edellyttäisi. Alueellinen levinneisyys ja opiskelun "avoimuus" eivät vielä poista eri väestöryhmien välillä olevia koulutuseroja. Tuntuu siltä, että tasa-arvosta puhutaan vain siitä syystä, että näin on saatu mukaan myös ns. "edistykselliset" koulutusbyrokraatit. Eihän kellään ole varaa vastustaa uudistusta, jossa puhutaan sivistyksellisen tasa-arvon edistämisestä. Vaikka avoimen korkeakoulun kokeilut lähtivätkin käyntiin sivistyksellisen tasaarvoajattelun innoittamana, niin useimmat tässä toiminnassa mukana olevista tietävät, ettei tavoitteita ole tässä suhteessa saavutettu. Tämä seikka pitäisi nyt kaikkien vihdoinkin tiedostaa ja tunnustaa. Vasta sen jälkeen päästään avoimen korkeakoulun kehittämisessä todellisuutta vastaavalle pohjalle. Eikö voitaisi yhtä hyvin todeta se tosiasia, että myös keskikoulun käyneillä ja ylioppilailla on oltava mahdollisuudet itsensä jatkuvaan kehittämiseen vaikkapa yliopistollisia arvosanoja suorittamalla, jos he näin haluavat. Eihän tässä mitään pahaa ole. Arvosanojen suorittamisesta ei kannata tehdä sen kummallisempaa asiaa kuin se todellisuudessa on. Kysymys on yliopistollisesta peruskoulutuksesta. Ei muutaman arvosanan suorittaminen ketään paremmaksi tee, jos ei pahemmaksikaan. Parhaimmillaan se voi avartaa henkilön maailmankatsomusta ja auttaa häntä paremmin ymmärtämään tätä yhteiskuntaa, itseään ja muita ihmisiä. Sen sijaan tieteellisen ajattelun oppiminen on jo niin vaativa tavoite, että se tahtoo päätoimisilta yliopisto-opiskelijoiltakin jäädä saavuttamatta. Avoimen korkeakoulun pakostakin sirpalemaisesti järjestetty opetus ei edesauta tämän tavoitteen saavuttamista. Kyseenalaiseksi tämän tavoitteen tekee myös se, että opettajat vastaavat avoimessa korkeakoulussa vain omasta opetuksestaan, jolloin heillä ei ole kokonaisvastuuta opiskelijoiden henkisestä kasvusta. Peruskysymys on siis se, miten luoda tieteellisen ajattelun edellyttämä "'henkinen ilmapiiri" avoimessa korkeakoulussa. Tätä ongelmaa ei ole toimikunnan mietinnössä käsitelty lainkaan. 


\section{Kansansivistystehtävä laiminlyöty}

Vaikka toimikunta onkin lähtenyt siitä aivan oikeasta perusajatuksesta, että korkeakoulujen pitäisi lähentyä muuta yhteiskuntaa, niin se on supistanut tämän lähentymisen aivan liian kapea-alaiseksi. Sehän pohtii vain arvosanaopetuksen ja yliopistollisten tutkintojen opiskelumahdollisuuksien avaamista aikuisväestölle. Arvosanaopetus "pyörii"' jo joka tapauksessa. "Kokeilutoiminnasta" puhuminen sen yhteydessä voitaisiin varmaan jo rehellisyyden nimessä lopettaa. Tutkinnonsuorittamismahdollisuuksiakin on jo olemassa, vaikka toimikunta ei tätä jostain syystä tuokaan esille (erikoistapauksina yliopistoissa opiskelevat). Sen sijaan yliopistot ovat laiminlyöneet lähes kokonaan varsinaisen kansansivistystehtävänsä.

Mielenkiintoinen ia kannatettava ajatus on yhteiskunnallisen tutkinnonn henkiinherättäminen. Se soveltuisi nimittäin erittäin hyvin kaikelle kansalle tarkoitetuksi yleissivistäväksi perustutkinnoksi. Paitsi että siinä annettaisiin korkeakouluopiskelun edellyttämät perusvalmiudet, niin siinä voitaisiin ohjata opiskelijoita tieteelliseen ajatteluun ja yhteiskunnan ja ihmisen syvällisempään tuntemukseen. Tutkinnon tulisi - kuten ennenkin - antaa kelpoisuus jatkaa opintojaan tiedekunnissa. Tämän tutkinnon kehittäminen aikuisväestölle sopivaksi olisi todella askel kohti sivistyksellistä tasa-arvoa. Valitettavasti toimikunta ei ole tuonut tämän tutkinnon kehittämistä tarpeeksi painokkaasti esiin, vaan se hukkuu muiden esitysten joukkoon. Toisena mahdollisuutena ovat erilaiset studia generaliatilaisuudet, joiden tarpeen mm. Kriittinen korkeakoulu on osoittanut. Varmasti muitakin mahdollisuuksia löytyy, jos niitä tosissaan aletaan pohtia. Näiltä osin toimikunnan mietintö on jäänyt varsin pinnalliseksi ja vähän uusia ajatuksia antavaksi.

\section{Korkeakoulujen kehittäminen avoimen korkeakoulun perusta}

On muistettava, että vaikka avoimen korkeakoulun kehittäminen liittyy aikuiskasvatukseen, niin se on ensisijaisesti nähtävä osana korkeakoululaitoksemme uudistamista. Olisi tarkkaan pohdittava, mikä sen asema ja merkitys on juuri tässä kontektissa. Sen kehittämisen yhteydessä kiivaillaan yhtenä päivänä ankarasti opiskeluoikeutta koskevien pykälien väljentämisestä, toisena päivänä korkeakoulun alueellisesta laajentamisesta, kolmantena ETÄ-opiskelun runsaammasta soveltamisesta korkeakouluopetuksessa sekä lopulta tieteellisen ajattelun ja tiedon levittämisestä koko väestön "'omaisuudeksi". Käsite "avoin korkeakoulu" - vaikka se nyt on vakiintunut ja sinänsä arvokas - tuntuu monissa tapauksissa yhdistävän näitä korkeakoulujen toiminnan kehittämisen kysymyksiä hyvin epätarkoituksenmukaisella tavalla toisiinsa. Miksei voitaisi keskustella erikseen korkeakoulujen perusopetuksen alueellisesta laajentamisesta ja ETÄopetuksen käytöstä perusopetuksessa; keinoista ja tavoista, joilla tieteellistä ajattelua voitaisiin levittää laajojen väestöpiirien "omaisuudeksi" ja miten uudesta tieteellisestä tiedosta voitaisiin yleistajuisesti tiedottaa. Monien erityyppisten kysymysten kytkeminen samaan käsitteeseen hämärtää avoimen korkeakoulun tehtävien määrittelyä.

Toimikunta toteaa, että se pitää aikuiskoulutuksen kehittämissuunnitelmia työnsä yleisenä viitekehyksenä. Mielenkiintoista on, että se ei ole hakenut viitekehystään korkeakoulun kehittämissuunnitelmista. Tämä johtuu ilmeisesti siitä, että korkeakoulujen kehittämissuunnitelmissa avoimen korkeakoulun kehittäminen on vuorossa vasta sen jälkeen, kun tieteellisen peruskoulutuksen ja jatkokoulutuksen edellytykset on turvattu (Korkeakoulutieto $2 / 1981$ ). Viitekehyksen hakeminen aikuiskasvatuksen kehittämissuunnitelmista johtuu ilmeisesti siitä, että siellä näyttää resurssien saanti olevan joka tapauksessa helpompaa. Koska avoimen korkeakoulun "'kokeilujen"' laajentaminen edellyttää ennen muuta korkeakoulujen resurssien lisäämistä, niin olisi ilmapiiriä selventävää siirtää sen kehittäminen pääasiassa korkeakoulujen kehittämistoiminnan piiriin. Muuten siitä saattaa muodostua "varsinaisten" aikuiskasvatusorganisaatioiden kehittämisresurssit hotkiva käenpoikanen. Tällaisia piirteitä toiminnalla on jo havaittu olevankin. On herätty kyselemään, mitkä ovat arvosanaopetuksen "järkevät" rajat eri aikuisoppilaitosten opetusohjelmissa. Tätä on kysellyt Paavo Suvanto (Kansanopisto 8/1980) kansanopistojen ja Paula Tuomikoski (Opistolehti 1/1981) kansalaisopistojen osalta. Tämä on johtunut siitä, että pelätään näiden organisaatioiden varsinaisen toiminnan ja identiteetin kärsivän, jos niiden opetus suunnataan liian yksipuolisesti yliopistolliseen arvosanaopetukseen.

Siitä missä määrin toimikunta on todella suhteuttanut omia vaatimuksiaan aikuiskasva- 
tukselliseen viitekehykseen antaa jonkinlaisia viitteitä mm. toimikunnan esittämä arvio päätoimisten suunnittelu- ja hallintohenkilöiden tarpeesta. Sen mukaan näitä tarvittaisiin 20-30 henkilöä. Lisäksi toimikuntà esittää, että tarvitaan huomattava määrä sivutoimisia ja luottamuspohjalta toimivia henkilöitä. Voi vain kysyä, miten nämä luvut ovat tasapainossa muiden aikuiskasvatusorganisaatioiden tarpeitten kanssa? Avoimessa korkeakoulussa opiskelee vuosittain noin 4000 opiskelijaa, vapaan sivistystyön piirissä sen sijaan lähes 800 000. Milloinkahan esim. tälle sektorille saataisiin suunnittelu- ja hallintotehtäviin 30 uutta, päätoimista virkaa?

- No, ei niitä ole vielä saatu avoimen korkeakoulun toimintaankaan, tuskin saadaankaan aivan lähiaikoina. Tätä ei lupaillut edes opetusministeri toimikunnan jättäessä sille mietintönsä. 